\title{
COMPOSITION AND CONCENTRATION OF SERUM FATTY ACIDS OF PHOSPHOLIPIDS DEPEND ON TUMOUR LOCATION AND DISEASE PROGRESSION IN COLORECTAL PATIENTS
}

\author{
SASTAV I KONCENTRACIJA SERUMSKIH MASNIH KISELINA U FOSFOLIPIDIMA ZAVISNO \\ OD MESTA TUMORA I PROGRESIJE OBOLENJA U KOLOREKTALNIH PACIJENATA
}

\author{
Bugajska Jolanta1, Berska Joanna1, Hodorowicz-Zaniewska Diana², Sztefko Krystyna1 \\ ${ }^{1}$ Clinical Biochemistry Department, IP, Jagiellonian University College of Medicine, Krakow, Poland \\ ${ }^{2}$ First Department of Surgery, Jagiellonian University College of Medicine, Krakow, Poland
}

\section{Summary}

Background: Polyunsaturated fatty acids (PUFAs) play a role in the development/progression of colon cancer. The aim of the study was to assess the relation between serum phospholipids PUFAs, colorectal tumour localization and disease progression.

Methods: A total of 67 patients (18 with proximal colon, 17 with distal colon and 32 with rectal tumour localization) as well as 16 controls were studied. One year after surgery, 33 patients had disease progression. Serum levels of C16:1(n-7), C18:1(n-9), C18:3(n-3),C20:5(n-3), C22:6(n3), $C 18: 2(n-6), C 20: 2(n-6), C 20: 4(n-6)$ fatty acids of serum phospholipids were quantitatively measured before surgery by gas-chromatography.

Results: Significantly higher mean value of C18:2, as compared to control, has been noted only for patients with proximal $(p<0.05)$ and distal tumour $(p<0.03)$ localization. The lower mean level of C20:5 and unsaturation index (UI) were observed in colorectal cancer patients regardless the tumour localization, but the statistical difference was noted only for patients with proximal tumours $(p<0.05, p<0.03)$. In patients with proximal tumours, significantly lower mean level of C20:4 and UI were noted in patients with disease progression, as compared to patients with proximal tumours without disease progression $(p<0.05)$.

\begin{abstract}
Kratak sadržaj
Uvod: Polinezasićene masne kiseline (PUFA) imaju značajnu ulogu u razvoju/progresiji karcinoma kolona. Cilj ovog proučavanja je da ispita odnos između PUFA serumskih fosfolipida, lokalizacije kolorektalnog tumora i progresije oboljenja. Metode: Proučavano je ukupno 67 pacijenata (18 sa rektalnim tumorom lokalizovanim na proksimalnom kolonu, 17 na distalnom kolonu i 32 u rektalnom delu), kao i 16 kontrolnih osoba. Nivoi serumskih masnih kiselina C16:1(n-7), C18:1(n-9), C18:3(n-3), C20:5(n-3), C22:6(n-3), C18:2 (n6), C20:2(n-6), C20:4(n-6) u fosfolipidima mereni su kvantitativno pre hirurške intervencije gasnom hromatografijom. Rezultati: Nađene su značajno više srednje vrednosti C18-2 u odnosu na kontrolnu grupu samo kod pacijenata sa proksimalnim $(p<0,05)$ i distalnim $(p<0,03)$ tumorom. Niže srednje vrednosti C20:5 i nesaturacioni indeks (UI) nađeni su kod pacijenata sa kolorektalnim tumorom, mada je statistička razlika zabeležena samo za pacijente sa proksimalnim tumorom $(p<0,05, p<0,03)$. U pacijenata sa proksimalnim tumorom značajno niže srednje vrednosti C20:4 i UI su nađene kod pacijenata sa progresijom oboljenja u poređenju sa pacijentima sa proksimalnim tumorom bez progresije $(p<0,05)$.

Zaključak: Procena PUFA kao rizik/prognostičkog faktora u pacijenata sa kolorektalnim tumorom može da se koristi za procenu lokalizacije tumora kao zavisno promenljiva vrednost.
\end{abstract}

Address for correspondence:

Jolanta Bugajska

Clinical Biochemistry Department, IP,

Jagiellonian University College of Medicine, Krakow,

Wielicka St. 265, Krakow 30-663, Poland

Telephone/Fax: +48126580681

jola.bugajska@uj.edu.pl
List of abbreviations: AA, arachidonic acid; COX, cyclooxygenase; DHA, docosahexaenoic acid; EPA, eicosapentaenoic acid; FAs, fatty acids; LA, linoleic acid; MUFAs, monounsaturated fatty acids; PUFAs, polyunsaturated fatty acids; UI, unsaturation index. 
Conclusions: The evaluation of PUFAs as a risk/prognostic factor in colorectal cancer patients should take into account tumour localization as a dependent variable.

Keywords: polyunsaturated fatty acids, n-3 fatty acids, n-6 fatty acids, phospholipids, colorectal cancer

\section{Introduction}

Colorectal cancer is not only a very heterogenous disease but also various subsites of tumour location can be seen. It has been proposed that colorectal cancer should be categorized into proximal and distal to the splenic flexure localization (1). It was suggested that the risk of colon cancer from environmental and genetic factors is different for tumours located in proximal and distal locations (1). Recently, Li and Lai (2) presented the evidence that colorectal cancer should be divided into proximal colon cancer, distal colon cancer, and rectal cancer because differences in physiology and anatomy, environmental carcinogens, genetic mechanisms, and prognosis between these three cancer locations have been shown. According to Sasazuki et al. (3), marine n-3 polyunsaturated fatty acids (PUFAs) and specific PUFAs are inversely related to the risk of colon cancer in the proximal site and no such association for $n-6$ PUFAs has been observed. Hodge et al. (4) observed a positive association with dietary palmitic acid, MUFAs and n-6 PUFAs for rectal but not for colon cancers. These could explain very conflicting data regarding the relation between $n$-fatty acids and colorectal cancer risk or progression.

Literature evidence suggests that the diet plays an important role in colorectal cancer etiology and development. There is a strong association between dietary intake of saturated fat and colon cancer risk (5). On the other hand, it has been shown that n-3 fatty acids may be responsible for reduced cancer risk (6) or have no influence on cancer risk (7). Gerber (8), based on a systematic update review of epidemiological studies, summarized that limited evidence and experimental data suggest a possible relationship between n-3 PUFAs and colorectal cancer. However, results of different studies regarding the role of fatty acids (FAs) in colorectal cancer are conflicting, and no convincing data exist linking FAs with the risk of the disease (9). Also, the link between FAs serum levels and localization of the tumour is not well known.

Numerous papers have already been published on the importance of fatty acids in colorectal cancer risk and prevention. However, little data exists on the fatty acids of phospholipids fraction in patients with colorectal cancer in relation to disease stage and tumour location. Fatty acids of the phospholipids fraction reflect the amount of fatty acids consumed with a diet. It is known that the amount of monounsaturated fatty acids (MUFAs) and polyunsaturated fatty acids (PUFAs) correlates with the proportion of fatty
Ključne reči: polinezasićene masne kiseline, n-3 masne kiseline, $n-6$ masne kiseline, fosfolipidi, kolorektalni karcinom

acids content in the serum phospholipids fraction (10), thus individual fatty acids are not only good markers of early dietary habits $(11,12)$ but may be markers of cancer progression. The aim of the study was to evaluate the link between the fatty acids of phospholipids fraction, tumour localization and cancer progression in colorectal cancer patients.

\section{Materials and Methods}

Sixty-seven consecutive patients with colorectal cancer (37 men and 30 women, mean age $63.4 \pm 10.2$ years) were selected from patients attending the tertiary care University Hospital in Krakow, Poland. The clinical diagnosis was based on physical examination, colonoscopy, endorectal USG, abdominal CT, and histopathology of tissue specimens according to Astler-Coller classification. Each patient underwent open surgery in order to remove the tumour. The patients with diabetes mellitus or glucose intolerance assessed based on fasting plasma glucose level and oral glucose tolerance test (OGTT) were excluded from the study. The study was approved by the local Ethical Committee (KBET/14/B/2006, resumed and expanded in 2013).

According to the UICC/AJCC classification, two patients $(3 \%)$ were in stage 0 of the disease, 24 patients $(35.8 \%)$ in stage I, four patients $(6 \%)$ in stage II, 12 patients (17.9\%) in stage III and 25 patients (37.3\%) in stage IV. In 18 patients (26.9\%) the tumour was localized in the proximal colon, in 17 patients $(25.4 \%)$ in the distal colon and in 32 (47.8\%) patients the tumour localization was confined to the rectum. After one year of follow-up, 34 (50.7\%) patients were in stable condition and the remaining $33(49.3 \%)$ patients had disease progression. All patients were on free range diet. Sixteen healthy patients (four men, 12 women, mean age $48.0 \pm 12$ years) served as a control group. Both colorectal cancer patients and healthy subjects were on free diet.

Fasting blood samples were taken from each patient before surgery. Serum samples were stored at $-70{ }^{\circ} \mathrm{C}$ until biochemical measurement of serum fatty acids of the phospholipids fraction was performed. The analytical procedure consisted of a few separate steps: 1) extraction of serum total lipids by Folch et al. (13) method; 2) separation of lipid fraction on SepPakNH2 columns (Waters, Milford, Mass., USA) (14); $3)$ methylation $(15,16)$ and separation of the fatty acid from phospholipids fraction by gas-chromato- 
graphy (Agilent Technologies 6890N Network GC Systems, Wilmington, De., USA) equipped with Agilent J\&W HP-88 capillary column (100 m, $0.250 \mathrm{~mm}$, $0.20 \mu \mathrm{m}$ ) (Agilent Technologies, USA). As an internal standard, 1,2-dipentadecanoil-sn-glicero-3-phosphocholine (Sigma-Aldrich, Steinheim, Germany) was used. The method was calibrated using the calibration mixture (all fatty acids - Sigma-Aldrich, Steinheim, Germany) and method validation was performed by GC-MS (17). Plasma levels of $n-7$ (palmitoleic, C16:1), n-9 (oleic, C18:1), n-3 (alpha-linolenic, C18:3; eicosapentaenoic - EPA, C20:5; docosahexaenoic DHA, C22:6) and n-6 (linoleic, C18:2; eicosadienoic C20:2; arachidonic, C20:4) acids of phospholipids fraction were quantitatively measured by gas-chromatography. The concentrations of fatty acids from phospholipids fraction were expressed in $\mu \mathrm{mol} / \mathrm{L}$. The sum of monounsaturated fatty acids (MUFAs), polyunsaturated fatty acids of $n-3$ series (PUFAs $n-3$ ) and $\mathrm{n}-6$ (PUFAs $\mathrm{n}-6$ ) series and unsaturation index (UI) were calculated using the following formulas:
MUFAs $=$ C16:1 + C18:1;

PUFAs n-3 = C18:3 + C20:5 + C22:6;

PUFAs n-6 = C18:2 + C20:2 + C20:4;

$\mathrm{UI}=\mathrm{C} 16: 1+\mathrm{C} 18: 1 \mathrm{cis}+\mathrm{C} 18: 2 \mathrm{cis} \times 2+\mathrm{C} 18: 3 \times 3$

$+C 20: 2 \times 2+C 20: 4 \times 4+C 20: 5 \times 5+C 22: 6 \times 6$.

Also, the ratio of $n-6$ to $n-3$ fatty acids was calculated.

Statistical analysis was performed with the software of Statistica 8.0 (StatSoft Inc., Krakow, Poland). The data are presented in the form of typical descriptive statistics (mean, SE). The Shapiro-Wilk's test was used to determine the normality of data distribution. Between groups comparison was performed using one-way ANOVA test with Tukey's (unequal N) post hoc test. The level of statistical significance was established at $p<0.05$.

\section{Results}

High inter-individual variability for all mono- and polyunsaturated fatty acids measured, both in

Table I Mono- and polyunsaturated serum fatty acids $(\mu \mathrm{mol} / \mathrm{L})$ of phospholipids fraction in colorectal cancer patients in relation to tumour localization.

\begin{tabular}{|c|c|c|c|c|c|c|}
\hline \multirow{3}{*}{\multicolumn{2}{|c|}{$\begin{array}{l}\text { Fatty acid } \\
{[\mu \mathrm{mol} / \mathrm{L}]}\end{array}$}} & \multicolumn{5}{|c|}{ Colorectal cancer patients } \\
\hline & & \multicolumn{5}{|c|}{ Tumour localization } \\
\hline & & $\begin{array}{l}\text { Control } \\
n=16\end{array}$ & $\begin{array}{c}\text { All } \\
n=67\end{array}$ & $\begin{array}{c}\text { proximal } \\
n=18\end{array}$ & $\begin{array}{l}\text { distal } \\
\mathrm{n}=17\end{array}$ & $\begin{array}{l}\text { rectum } \\
n=32\end{array}$ \\
\hline Palmitoleic acid & C16:1 (n-7) & $14.4 \pm 2.2$ & $\begin{array}{c}19.35 \pm 0.96 \\
p<0.05^{*}\end{array}$ & $18.0 \pm 2.4$ & $18.7 \pm 2.5$ & $20.4 \pm 1.8$ \\
\hline Oleic acid & C18:1 (n-9) & $276.8 \pm 21.9$ & $301.1 \pm 10.1$ & $282.1 \pm 19.9$ & $304.0 \pm 19.9$ & $309.6 \pm 14.5$ \\
\hline Linoleic acid (LA) & C18:2 (n-6) & $503.8 \pm 42.7$ & $\begin{array}{c}643.4 \pm 19.7 \\
p<0.03^{*}\end{array}$ & $\begin{array}{c}661.8 \pm 38.7 \\
p<0.05^{*}\end{array}$ & $\begin{array}{c}679.2 \pm 38.7 \\
p<0.03^{*}\end{array}$ & $614.6 \pm 28.2$ \\
\hline$\alpha$-linolenic acid (ALA) & C18:3 (n-3) & $9.6 \pm 1.1$ & $\begin{array}{l}5.9 \pm 0.5 \\
p<0.03^{*}\end{array}$ & $6.1 \pm 1.0$ & $6.03 \pm 1.0$ & $5.8 \pm 0.7$ \\
\hline Eicosadienoic acid & $C 20: 2(n-6)$ & $18.5 \pm 1.5$ & $\begin{array}{c}9.5 \pm 0.5 \\
p<0.001^{*}\end{array}$ & $\begin{array}{c}9.4 \pm 1.0 \\
p<0.001 *\end{array}$ & $\begin{array}{l}10.0 \pm 1.1 \\
p<0.001 *\end{array}$ & $\begin{array}{c}9.3 \pm 0.8 \\
p<0.001^{*}\end{array}$ \\
\hline Arachidonic acid (AA) & C20:4 (n-6) & $523.7 \pm 30.7$ & $\begin{array}{c}386.0 \pm 13.9 \\
p<0.003^{*}\end{array}$ & $\begin{array}{c}378.5 \pm 27.1 \\
p<0.007^{*}\end{array}$ & $\begin{array}{c}389.8 \pm 27.9 \\
p<0.02 *\end{array}$ & $\begin{array}{c}388.2 \pm 18.3 \\
p<0.02 *\end{array}$ \\
\hline Eicosapentaenoic acid (EPA) & $C 20: 5(n-3)$ & $48.7 \pm 4.2$ & $\begin{array}{l}37.5 \pm 2.5 \\
p<0.05^{*}\end{array}$ & $\begin{array}{l}31.2 \pm 3.7 \\
p<0.05^{*}\end{array}$ & $36.9 \pm 4.9$ & $41.4 \pm 3.6$ \\
\hline Docosahexaenoic acid (DHA) & $C 22: 6(n-3)$ & $260.7 \pm 17.3$ & $\begin{array}{l}164.0 \pm 7.8 \\
p<0.001 *\end{array}$ & $\begin{array}{c}160.1 \pm 15.3 \\
p<0.001^{*}\end{array}$ & $\begin{array}{c}171.1 \pm 15.7 \\
p<0.003^{*}\end{array}$ & $\begin{array}{l}162.4 \pm 8.5 \\
p<0.001 *\end{array}$ \\
\hline Indices & & & & & & \\
\hline MUFAs & & $295.4 \pm 23.5$ & $320.4 \pm 10.8$ & $299.9 \pm 21.3$ & $322.8 \pm 21.3$ & $330.0 \pm 15.5$ \\
\hline PUFAs n-3 & & $319.0 \pm 20.8$ & $\begin{array}{c}205.3 \pm 9.8 \\
p<0.001^{*}\end{array}$ & $\begin{array}{c}200.3 \pm 19.4 \\
p<0.001^{*}\end{array}$ & $\begin{array}{c}208.4 \pm 19.4 \\
p<0.003^{*}\end{array}$ & $\begin{array}{c}206.3 \pm 14.4 \\
p<0.002^{*}\end{array}$ \\
\hline PUFAs n-6 & & $1046.0 \pm 60.8$ & $1053.8 \pm 28.8$ & $1074.5 \pm 56.9$ & $1099.0 \pm 58.7$ & $1021.1 \pm 40.9$ \\
\hline $\mathrm{UI} * 10^{3}$ & & $5.27 \pm 0.27$ & $\begin{array}{c}4.32 \pm 0.12 \\
p<0.02^{*}\end{array}$ & $\begin{array}{c}4.19 \pm 0.24 \\
p<0.03^{*}\end{array}$ & $4.48 \pm 0.24$ & $4.32 \pm 0.18$ \\
\hline PUFAs n-6/PUFAs n-3 & & $3.8 \pm 0.39$ & $\begin{array}{l}5.34 \pm 0.2 \\
p<0.007^{*}\end{array}$ & $\begin{array}{c}5.39 \pm 0.37 \\
p<0.03^{*}\end{array}$ & $5.56 \pm 0.39$ & $\begin{array}{c}5.20 \pm 0.28 \\
p<0.02^{*}\end{array}$ \\
\hline
\end{tabular}

Mean values \pm SE are given. * as compared to control

MUFAs - monounsaturated fatty acids, PUFAs $n-3$ - polyunsaturated fatty acids of $n-3$ series, PUFAs n- 6 - polyunsaturated fatty acids of $n-6$ series

UI - unsaturation index 


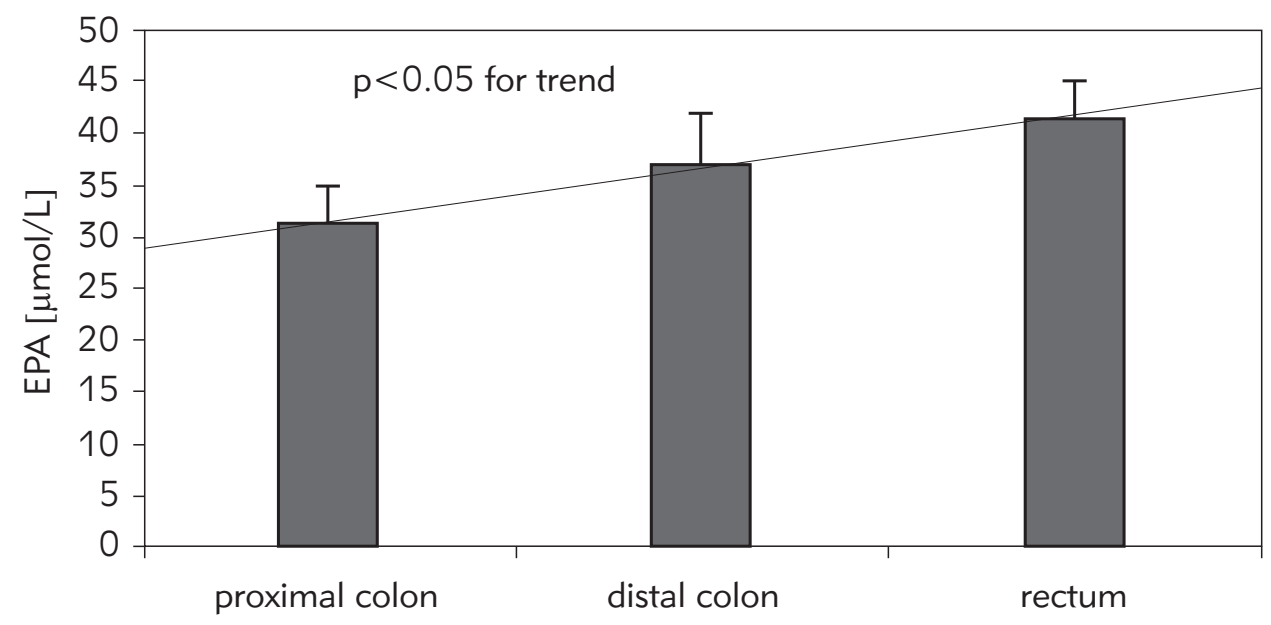

Figure 1 The mean concentration value of eicosapentaenoic acid (EPA) of serum phospholipid fraction in colorectal cancer patients in relation to tumour location.

patients and in controls, has been noted. However, there were no significant differences in the mean values of all measured fatty acids of phospholipids fraction and calculated indices between men and women and among patients with different stage of the disease. Taking into account all colorectal cancer patients, the mean serum concentrations of C16:1 (n-7) and C18:2 (n-6) were significantly higher and the mean levels of C18:3 (n-3), C20:2 (n-6), C20:4 $(n-6), C 20: 5(n-3)$ and C22:6 (n-3) were significantly lower as compared to control $(p<0.05-0.001)$. Only the mean values of $18: 1(n-9)$ obtained in colorectal cancer patients and in control were similar (Table I). Among the calculated indices, the mean values of MUFAs and PUFAs (n-6) did not differ between colorectal cancer patients and control. However, significantly lower mean values of PUFAs $(n-3)(p<0.001)$ and UI $(p<0.02)$ were noted for colorectal cancer patients as compared to control. The mean value of PUFAs (n-6) to PUFAs ( $n-3)$ ratio was significantly higher in colorectal cancer patients as compared to control $(p<0.007)$.

Taking into account tumour localization, similar mean values of the measured fatty acids were found except for linoleic acid (C18:2, n-6), EPA (C20:5, n$3)$ and UI. Significantly higher mean values of linoleic acid (C18:2, n-6), as compared to control, have been noted for patients with proximal and distal tumour localization but not for patients with tumours confined to the rectum. Although the mean values of EPA and Ul were lower than in control regardless the tumour localization, statistical difference was noted only for patients with proximal tumour localization (for EPA $\mathrm{p}<0.05$, for UI $\mathrm{p}<0.03$ ). Moreover, a significant trend toward increased values of EPA from the proximal part, to the distal part, to the rectum was noted $(p<0.05)$ (Figure 1).
In patients with proximal tumour localization who have had disease progression after one year of follow-up, a significantly lower mean value of C20:4 ( $n-6)$ has been observed as compared to the patients having the same tumour localization but disease free

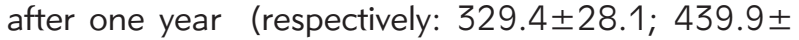
26.6; $p<0.05$ ). Patients with proximal tumour localization and disease progression had significantly lower mean values of $U I$ as compared to those without tumour progression (respectively: $3.73 \pm 0.22 ; 4.62 \pm$ $0.21 ; p<0.05)$. No other differences between the mean values of fatty acids measured in respect to disease progression were observed.

\section{Discussion}

Fatty acids are very important biological compounds which may be associated with different diseases (e.g. diabetes) or are linked with an increased risk of certain cancer. Literature evidence suggests that dietary lipids could play an important role in the etiology of colorectal cancer, although inconsistent results are frequently seen (18). The role of different lipids fraction has been already studied in cancer patients, but measurement of plasma phospholipids fatty acids can be considered as the most useful because a correlation exists between dietary fatty acid intake and the proportion of fatty acids in plasma phospholipids $(19,20)$. It is known that PUFAs content in phospholipids fraction is mainly of exogenous origin (11). Thus, it can be assumed that fatty acids of phospholipids fraction reflect, to some extent, the intake of fatty acids. Phospholipids are the predominant lipids of cell membranes.

The main goal of the present study was to find out the relationship between the fatty acids composi- 
tion in serum phospholipids fraction and tumour localization in colorectal cancer patients. Most significant finding in the present study is that the mean EPA $(\mathrm{C} 20: 5, \mathrm{n}-3)$ level and $\mathrm{UI}$ in patients with colorectal cancer had the lowest value in patients with tumours localized in the proximal part of the colon. The results are in agreement with the data of Fernandez-Bañares et al. (21) and Okuno et al. (22) who observed a significantly lower percentage of EPA in plasma phospholipids in colorectal cancer patients versus reference group. However, the cited authors (22) did not find significant differences in the proportion of any fatty acid between patients with cancer located in the proximal colon, distal colon and rectum. FernandezBañares et al. (21) noticed a significantly lower $\mathrm{UI}$ in cancer patients versus the control group. Their study group consisted of patients with tumours in the rectum, sigmoid colon and caecum plus ascending colon and they did not compare the UI between patient subgroups. In our study, a decrease in UI in all patients with colorectal cancer was observed; however, looking at the different tumour locations, such a decrease was noted only in patients with a proximal location of the cancer. This confirms that histology of the cell membrane in different parts of the intestine is variable. Differences in UI between colorectal cancer patients and controls indicate indirectly that any research connected with membrane fluidity should always take into consideration tumour localization. Sasazuki et al. (3), based on a questionnaire, in a large Japanese population-based study found that high fish consumption and a wide range of $n-3$ PUFAs of marine origin are inversely related to the risk of cancer in proximal sites of the large bowel. Significantly lower 5-year survival for patients with proximal colon cancer compared to distal colon cancer has also been published (23). Kantor et al. (24) noticed the association between fish oil supplement use and cancer risk to vary over anatomical subsite. The enhancement of fish oil use reduced risk of colon cancer, but not risk of rectal cancer.

The results of Okuno's study demonstrated no significant differences for C18:2 and C20:4 between patients with colorectal cancer and controls (22). Fernandez-Bañares et al. (21) and Baro et al. (25) showed a significantly lower percentage of linoleic acid in colorectal cancer patients than in a control group, while the percentage of arachidonic acid was similar to controls. In contrast, in our study the level of C18:2 was higher whereas C20:4 level was lower in colorectal cancer patients regardless of the tumour localization. The mean concentrations of DHA and PUFAs $n-3$ were lower in patients with cancer located in the proximal part, distal part of the colon and in the rectum as compared to the control group. However, in three other studies there were no significant differences for DHA between colorectal cancer patients and control group when fatty acid was expressed as a proportion of total FAs $(22,26,27)$. Hodge et al. (4) noticed an inverse association between plasma phospholipids docosahexaenoic acid and risk of rectal can- cer. The differences in fatty acids of phospholipids fraction between colon cancer patients observed in different studies can be due, in part, to modification in the metabolism of fatty acids in cancer patients, and in part to differences in dietary habits, race, and geographical areas. Our cancer patients and controls came from the same geographical area with a very homogenous population, and an assumption can be made that the diet in every subject was similar quantitatively.

Another important finding of our study is the significantly $(p<0.05)$ lower level of arachidonic acid (AA) in patients with disease progression after one year of observation as compared to the patients who were disease-free; however, this observation was only true for patients with proximal, but not distal or rectal tumour location. The AA, associated with membrane phospholipids, originates from linoleic acid (LA) present in the diet (28). The rate-limiting step in the production of AA from LA has been identified as microsomal $\Delta 6$ desaturation, and it has been elucidated that the inhibition of this desaturation encumbers tumorigenesis in a mouse model (29). AA is converted into eicosanoids with the help of cyclooxygenase (COX) and lipoxygenase. It is known that colonic epithelial cells transport dietary LA and convert LA to AA more rapidly during transformation/tumorigenesis (30). AA-derived eicosanoids have proinflammatory effects (31-33). EPA-derived eicosanoids have antiinflammatory effects (34). The fatty acid profile obtained in the present study differs from the results obtained in patients with familial adenomatous polyposis (35) in whom lower LA and higher AA as compared to control have been obtained. Metabolism of AA by COX enzymes (COX-1 or COX-2) leads to the synthesis of the 2-series of prostaglandins. Prostaglandin overproduction has various proinflammatory effects.

Some evidence indicates that MUFAs acids are associated with the presence of colorectal adenomas. Pickens et al. (36) showed that palmitoleic acid from plasma phospholipids fraction was significantly higher in individuals with adenomas compared to those with no polyps whereas the percentage of phospholipids oleic acid did not differ between these groups of patients. We obtained similar results.

Since lipid metabolism and the plasma profile of phospholipids fatty acids are altered in patients with colorectal cancer, it is suggested that levels of phospholipids FAs may be useful as one of the reliable biomarkers of this disease (36). Other authors (37) anticipated that analysis of serum metabolite patterns, including MUFAs and PUFAs, may become a standard clinical procedure for effective diagnosing and monitoring of patients sufferring from colorectal cancer.

Taking into account the dietary heterogeneity in the population and more or less constant dietary habits in each individual person, it is not surprising that the index of individuality (the ratio of intra-indivi- 
dual to inter-individual variation) is very low for each fatty acid, regardless of lipid's fraction. Any assumption on the population reference range for total or individual fatty acids of any origin is impossible. Proper interpretation of any research requires, among others, reference values from an optimally selected control group. In the case of fatty acids of any origin, proper selection of the control group is practically an unsolved problem due to the availability of different diets and high variety of the amount of food consumed by each single person. Evidence for this is the published information on the n-6 PUFAs/n-3 PUFAs ratio which give the number from 2.6:1 to 5.29:1 (38-40). One of the main reasons of such discrepancy is the increase in the consumption of n-6 fatty acids and a marked reduction in the consumption of n-3 fatty acids. In our control group, the lowest value of n-6 PUFAs/n-3 PUFAs ratio was 1.96:1 and the highest value was 6.8:1 with the mean value 3.8:1. The question which should be asked is which value of the calculated ratio should be taken when the results in cancer patients are evaluated: the mean value or median value obtained in a control group selected according to research criteria or should we take into account the specific value of the ratio e.g. 2:1? No

\section{References}

1. Bufill JA. Colorectal cancer: evidence for distinct genetic categories based on proximal or distal tumor location. Ann Intern Med 1990; 113(10): 779-88.

2. Li F, Lai M. Colorectal cancer, one entity or three. J Zhejiang Univ Sci B [Internet]. Hangzhou: Zhejiang University Press; 2009; 10(3): 219-29. Available from: http://www. ncbi.nlm.nih.gov/pmc/articles/PMC2650032/.

3. Sasazuki S, Inoue M, Iwasaki M, Sawada N, Shimazu T, Yamaji $T$, et al. Intake of $n-3$ and $n-6$ polyunsaturated fatty acids and development of colorectal cancer by subsite: Japan Public Health Center-based prospective study. Int J Cancer 2011; 129(7): 1718-29.

4. Hodge AM, Williamson EJ, Bassett JK, Maclnnis RJ, Giles GG, English DR. Dietary and biomarker estimates of fatty acids and risk of colorectal cancer. Int J Cancer 2015; 137(5): 1224-34.

5. Glade MJ. Food, nutrition, and the prevention of cancer: a global perspective. American Institute for Cancer Research/World Cancer Research Fund, American Institute for Cancer Research, 1997. Nutrition 1999; 15(6): 523-6.

6. Caygill CP, Charlett A, Hill MJ. Fat, fish, fish oil and cancer. Br J Cancer 1996; 74(1): 159-64.

7. MacLean CH, Newberry SJ, Mojica WA, Khanna P, Issa AM, Suttorp MJ, et al. Effects of omega-3 fatty acids on cancer risk: a systematic review. JAMA 2006; 295(4): 403-15.

8. Gerber M. Omega-3 fatty acids and cancers: a systematic update review of epidemiological studies. Br J Nutr 2012; 107 Suppl: S228-39. simple answer for such a simple question can be found in the literature.

The present study has certain limitations and shortcomings. First, the present study is only an experimental observation and no conclusion can be drawn regarding the patients survival. Nevertheless, lower EPA and AA in cancer patients than in controls have been confirmed. Taking into account the studies documenting worse outcomes of patients with proximal colon cancer (23), it might be speculated that the metabolism of EPA and AA in colorectal cancer patients is different. Second, our study group was relatively small and a large-scale prospective study is required to confirm our results.

In conclusion, in any research concerning the role of individual fatty acids in colorectal cancer risk and/or prevention, tumour localization should be taken into account as a dependent variable.

\section{Conflict of interest statement}

The authors stated that they have no conflicts of interest regarding the publication of this article.

9. Nkondjock A, Shatenstein B, Maisonneuve P, Ghadirian P. Specific fatty acids and human colorectal cancer: an overview. Cancer Detect Prev 2003; 27(1): 55-66.

10. Hodge AM, Simpson JA, Gibson RA, Sinclair AJ, Makrides M, O'Dea K, et al. Plasma phospholipid fatty acid composition as a biomarker of habitual dietary fat intake in an ethnically diverse cohort. Nutr Metab Cardiovasc Dis 2007; 17(6): 415-26.

11. Arab L. Biomarkers of fat and fatty acid intake. J Nutr 2003; 133 Suppl: 925S-932S.

12. Saadatian-Elahi $M$, Slimani $N$, Chajes $V$, Jenab $M$, Goudable J, Biessy C, et al. Plasma phospholipid fatty acid profiles and their association with food intakes: results from a cross-sectional study within the European Prospective Investigation into Cancer and Nutrition. Am J Clin Nutr 2009; 89(1): 331-46.

13. Folch J, Lees M, Sloane Stanley GH. A simple method for the isolation and purification of total lipids from animal tissues. J Biol Chem. Not Available; 1957; 226(1): 497509.

14. Kaluzny MA, Duncan LA, Merritt M V, Epps DE. Rapid separation of lipid classes in high yield and purity using bonded phase columns. J Lipid Res 1985; 26(1): 13540.

15. Morrison WR, Smith LM. Preparation of fatty acid methyl esters and dimethylacetals from lipids with boron fluoridemethanol. J Lipid Res 1964; 5: 600-8.

16. Kang JX, Wang J. A simplified method for analysis of polyunsaturated fatty acids. BMC Biochem 2005; 6: 5. 
17. Bugajska J, Berska J, Hodorowicz-Zaniewska D, Sztefko K. Walidacja metody oznaczania kwasów tłuszczowych frakcji fosfolipidów w surowicy krwi. Validation of the method of determination of phospholipid fraction fatty acids in blood serum. Diagnostyka Laboratoryjna 2010; 46(2): 125-30.

18. Chen G, Qin L, Lu D, Han T, Zheng Y, Xu G, Wang X. $\mathrm{N}-3$ polyunsaturated fatty acids intake and risk of colorectal cancer: meta-analysis of prospective studies. Cancer Causes Control 2015; 133-41.

19. Hall MN, Campos H, Li H, Sesso HD, Stampfer MJ, Willett WC, et al. Blood levels of long-chain polyunsaturated fatty acids, aspirin, and the risk of colorectal cancer. Cancer Epidemiol Biomarkers Prev 2007; 16(2): 314-21.

20. Hall MN, Chavarro JE, Lee I-M, Willett WC, Ma J. A 22year prospective study of fish, n-3 fatty acid intake, and colorectal cancer risk in men. Cancer Epidemiol Biomarkers Prev 2008; 17(5): 1136-43.

21. Fernandez-Banares F, Esteve M, Navarro E, Cabre E, Boix J, Abad-Lacruz A, et al. Changes of the mucosal n3 and n6 fatty acid status occur early in the colorectal adenoma-carcinoma sequence. Gut 1996; 38(2): 254-9.

22. Okuno M, Hamazaki K, Ogura T, Kitade H, Matsuura T, Yoshida $\mathrm{R}$, et al. Abnormalities in fatty acids in plasma, erythrocytes and adipose tissue in Japanese patients with colorectal cancer. In Vivo 2013; 27(2): 203-10.

23. Wong R. Proximal Tumors Are Associated with Greater Mortality in Colon Cancer. J Gen Intern Med [Internet]. New York: Springer-Verlag; 2010; 25(11): 1157-63.

24. Kantor ED, Lampe JW, Peters U, Vaughan TL, White E. Long-chain omega-3 polyunsaturated fatty acid intake and risk of colorectal cancer. Nutr Cancer 2014; 66(4): 716-27.

25. Baro L, Hermoso JC, Nunez MC, Jimenez-Rios JA, Gil A. Abnormalities in plasma and red blood cell fatty acid profiles of patients with colorectal cancer. Br J Cancer 1998; 77(11): 1978-83.

26. Chapkin RS, Davidson LA, Ly L, Weeks BR, Lupton JR, McMurray DN. Immunomodulatory effects of (n-3) fatty acids: putative link to inflammation and colon cancer. J Nutr 2007; 137(1 Suppl): 200S-204S.

27. Yuksel M, Ates I, Kaplan M, Fettah Arikan M, Yasemin Ozderin Ozin, Kilic ZMY, Topcuoglu C, Kayacetin E. Is oxidative stress associated with activation and pathogenesis of inflammatory bowel disease? J Med Biochem 2017; 36: DOI: 10.1515/jomb-2017-0013

28. Urquhart P, Parkin SM, Rogers JS, Bosley JA, Nicolaou A. The effect of conjugated linoleic acid on arachidonic acid metabolism and eicosanoid production in human saphenous vein endothelial cells. Biochim Biophys Acta 2002; 1580(2-3): 150-60.
29. Hansen-Petrik MB, McEntee MF, Johnson BT, Obukowicz MG, Masferrer J, Zweifel B, et al. Selective inhibition of $\Delta-6$ desaturase impedes intestinal tumorigenesis. Cancer Lett 2002; 175(2): 157-63.

30. Jones R, Adel-Alvarez L-A, Alvarez OR, Broaddus R, Das $\mathrm{S}$. Arachidonic acid and colorectal carcinogenesis. Mol Cell Biochem 2003; 253(1-2): 141-9.

31. Cowing BE, Saker KE. Polyunsaturated fatty acids and epidermal growth factor receptor/mitogen-activated protein kinase signaling in mammary cancer. J Nutr 2001; 131(4): 1125-8.

32. Calder PC, Grimble RF. Polyunsaturated fatty acids, inflammation and immunity. Eur J Clin Nutr 2002; 56 Suppl 3: S14-9.

33. Calder PC, Yaqoob P, Thies F, Wallace FA, Miles EA. Fatty acids and lymphocyte functions. Br J Nutr 2002; 87 Suppl 1: S31-48.

34. Zhang C, Yu H, Ni X, Shen S, Das UN. Growth inhibitory effect of polyunsaturated fatty acids (PUFAs) on colon cancer cells via their growth inhibitory metabolites and fatty acid composition changes. PLoS One 2015; 10(4): e0123256.

35. Almendingen K, Hostmark AT, Fausa O, Mosdol A, Aabakken L, Vatn MH. Familial adenomatous polyposis patients have high levels of arachidonic acid and docosahexaenoic acid and low levels of linoleic acid and alphalinolenic acid in serum phospholipids. Int J Cancer 2007; 120(3): 632-7.

36. Pickens CA, Lane-Elliot A, Comstock SS, Fenton JI. Altered Saturated and Monounsaturated Plasma Phospholipid Fatty Acid Profiles in Adult Males with Colon Adenomas. Cancer Epidemiol Biomarkers Prev 2016; 25(3): 498-506.

37. Chen L, Zhang C, Gui Q, Chen Y, Yang Y. Ultra performance liquid chromatography coupled with quadrupole time of flight mass spectrometry based metabolic profiling of human serum prior to and following radical resection of colorectal carcinoma. Mol Med Rep Spandidos Publications 2015; 12(5): 6879-86.

38. Chajes V, Thiebaut ACM, Rotival M, Gauthier E, Maillard $V$, Boutron-Ruault M-C, et al. Association between serum trans-monounsaturated fatty acids and breast cancer risk in the E3N-EPIC Study. Am J Epidemiol 2008; 167(11): 1312-20.

39. Ogura T, Takada H, Okuno M, Kitade H, Matsuura T, Kwon $M$, et al. Fatty acid composition of plasma, erythrocytes and adipose: their correlations and effects of age and sex. Lipids 2010; 45(2): 137-44.

40. Bjorndal B, Strand E, Gjerde J, Bohov P, Svardal A, Diehl BW, et al. Phospholipids from herring roe improve plasma lipids and glucose tolerance in healthy, young adults. Lipids Health Dis 2014; 13: 82. 